\title{
Phenotypic characterization of chicken inbred lines that differ extremely in growth, body composition and egg production traits
}

\author{
ZEMELAK GORAGA*, MOSTAFA NASSAR*, GERD-PETER SCHRAMM and GUDRUN A. \\ BROCKMANN
}

Breeding Biology and Molecular Genetics, Department for Crop and Animal Sciences, Faculty of Agriculture and Horticulture, Humboldt-Universität zu Berlin, Germany

\section{Abstract}

The development of phenotypically and genetically divergent inbred chicken lines as simplified genetic models facilitates the identification of genes and contributes to the elucidation of gene functions. In this study, we characterized a New Hampshire (NH) population with its partial inbred derivative, New Hampshire inbred (NHI), and a White Leghorn inbred line (WL77). Both NHI and WL77 lines were inbred after selection for high meat yield or low egg weight, respectively. The inbreeding levels in NHI and WL77 are about $86 \%$ and $100 \%$, respectively. Animals of the NHI line grew twice as fast, were about two times as heavy at 20 weeks, and deposited 9.3 times as much fat as WL77. NHI females reached sexual maturity, indicated by age at first egg, earlier, had a $35 \%$ higher egg production ratio, and their eggs were on average $6 \mathrm{~g}$ heavier compared to WL77 females. The NHI and WL77 lines were extremely different for most traits, which makes them suitable for cross-bred experiments to map quantitative trait loci and identify genes contributing to the observed differences.

Keywords: inbreeding, animal model, muscle, fat, reproduction

\section{Zusammenfassung}

\section{Phänotypische Charakterisierung von Hühnerinzuchtlinien, die sich extrem im Wachstum, der Körperzusammensetzung und der Legeleistung unterscheiden}

In den letzten Jahren wurden mehrfach Inzuchtlinien geschaffen, die vereinfachte Modelle für genetische Untersuchungen bilden. Im vorliegenden Beitrag werden die Historie und die Eigenschaften von Inzuchtlinien der Rassen New Hampshire (NH) und White Leghorn (WL77), die über 7 bzw. mehr als 50 Generationen eingezüchtet wurden, beschrieben. Von der Ursprungspopulation der New Hampshire Inzuchtlinie NHI existiert auch die weiter gezogene Basispopulation NH. Die NH Population und die NHI Linie zeichnen sich durch hohen Fleischansatz aus, während die Weißen Leghorns aus einer auf geringe Legeleistung selektierten Ausgangspopulation abstammen. Aufgrund der unterschiedlichen genetischen Herkunft und der extrem verschiedenen Merkmalsentwicklung eigenen sich die erzeugten Inzuchtlinien sehr gut für Kreuzungen zur Identifizierung von Genen, die zur Merkmalsdifferenz beitragen.

Schlüsselwörter: Inzucht, Tiermodell, Muskel, Fett, Fruchtbarkeit 


\section{Introduction}

Chickens have long been a major source of protein for their meat and eggs and an important model organism for developmental biology (BURT and WHITE 2007). A number of genetic and environmental factors affect meat and egg production. Gene variants contribute to the variability of the traits. Heritability values for body weight and growth traits are high, estimated between 0.21 and 0.68 (LE BIHAN-DUVAL et al. 2001, ZHANG et al. 2003, GAYA et al. 2006, KAMALI et al. 2007). Heritability values of 0.42-0.52, 0.31-0.69, and 0.28-0.6 were reported for age at first egg, egg number and egg weight, respectively, in different outbred chickens (WEI and VAN DER WERF 1995, HARTMANN et al. 2003, BUITENHUIS et al. 2004, WOLC et al. 2007, LWELAMIRA et al. 2009).

The identification of genes contributing to production traits in chicken would allow the targeted search for genetic variation in these genes in breeding populations to use favored alleles for selection. Therefore, genetic studies have been performed to map genes and genomic loci that affect growth, body composition (MCELROY et al. 2006, ZHOU et al. 2006, CAMPOS et al. 2009), and reproduction traits (TUISKULA-HAAVISTO et al. 2002, SASAKI et al. 2004, HANSEN et al. 2005, SCHREIWEIS et al. 2006). If inbred lines of diverse selection lines are used for gene mapping experiments, the probability is very high that different alleles contributing to different traits segregate in the mapping population, and thus these genetic differences can be identified. These mapping populations permit also the identification of epistatic interactions between genetic loci (CARLBORG et al. 2005). In addition to advantages in QTL-mapping studies, inbred lines allow the unlimited production of animals of the same genotype for repeated and comprehensive phenotypic characterization.

In the 50th of the last century, a number of chicken inbred lines were generated from different origin. With the development of large scale genotyping and sequencing approaches, these lines were intensively used for the identification of genetic variation. For example, LONERGAN et al. (2003) exploited inbred Leghorn and Fayoumi lines for the study of breast meat quality and composition. ZHOU et al. (2007) used inbred Leghorn and Fayoumi as parental lines to produce an $\mathrm{F}_{2}$ population for a whole-genome QTL scan. Inbred lines of White Leghorn, Fayoumi, and New Hampshire have also been used for genetic studies of production traits for a long time (ZHOU et al. 1999, DEEB and LAMONT 2002, SZWACZKOWSKI et al. 2003, DENNIS et al. 2004, JUUL-MADSEN et al. 2006, KIM et al. 2008).

In this study we present the inbred White Leghorn (WL77), the partially inbred New Hampshire (NHI), and the outbred New Hampshire $(\mathrm{NH})$ lines. The outbred $\mathrm{NH}$ line was the original founder population for the inbred derivate, $\mathrm{NHI}$, and still exists. Both $\mathrm{NHI}$ and WL77 are unique lines that were inbred after selection for high meat yield and low egg weight, respectively. The inbreeding level in WL77 is close to $100 \%$, while about $86 \%$ in $\mathrm{NHI}$ and about $27 \%$ in $\mathrm{NH}$. These three lines serve as valuable resources for genetic studies to identify the genetic variation contributing to the extreme trait differences. A crossbred population between NHI and WL77 has been generated to facilitate gene mapping. In this initial paper, we describe the origin of the lines and characterized them for their inbred status and for growth parameters, body composition, and egg production traits. 


\section{Material and methods}

\section{Chicken lines}

The outbred New Hampshire (NH) population was founded between 1955 and 1957 at Humboldt-Universität zu Berlin, Germany with NH chicken from different breeders in the region of Brandenburg and Greater Berlin, Germany. Chickens had been selected for high meat yield. In 1957, the population consisted of 8 flocks, each with 1 male and 11 to 16 females. Since 1976, the population has been kept to 15 flocks. Males were selected for high semen volume and quality, and females were selected for high egg performance and fertility. At 40 weeks 1 cock and 5 hens were reproduced in a rotation system where cocks systematically rotate between the flocks to minimize inbreeding. The estimated inbreeding coefficient after 43 generations was $26.6 \%$ by IRGANG (2001). Since 2001 the outbred population was continued with 4 flocks. Flocks were selected as before for the highest laying performance in hens and fertility in males. At present, in every flock 10 female and 5 male chicks are randomly selected after hatch. The rotation system for mating 1 cock with 5 females is continued.

The $\mathrm{NH}$ inbred line (NHI) was generated as an inbred derivative of $\mathrm{NH}$ by repeated brother-sister mating, beginning in 1999. In NHI inbreeding was performed initially in 6 randomly chosen full sibs building 6 families. In every family, 1 to 2 cocks were mated with 5 to 8 hens. In generations 1 to 3 , those families were selected for further inbreeding which had an optimal sex ratio of at least 5 males and 5 females. In females, the egg laying performance was recorded from the beginning of egg laying until 64 weeks. The number of eggs at 40 weeks and the mean egg weight of hens were used for selecting best hens for further reproduction. Males were selected for best ejaculate quality measured as sperm motility, sperm concentration, and ejaculate volume. In the first three generations four families were lost because of low vitality and infertility. Beginning with the 4th generation of inbreeding, 3 cocks were mated with 3 to 10 hens, depending on the number of vital and fertile hens at the time of reproduction at 40 weeks. No further trait selection was performed. The NHI chickens that we analyzed in this study belong to the 6th inbreeding generation. The inbreeding coefficient was calculated to be $86 \%$ on the basis of the pedigree taking into account an initial inbreeding coefficient of $26.6 \%$ which was estimated by IRGANG (2001) and subsequent 6 generations of brother-sister mating. Based on genotype information of microsatellite markers (unpublished data), 27 out of 174 were heterozygous, indicating an inbreeding level about $84 \%$, which conforms the estimated value.

The White Leghorn (WL77) line was established with 4 American White Leghorn and 4 Swiss White Leghorn lines at the Eidgenössische Technische Hochschule Zürich, Switzerland in 1960. After several rounds of reproduction, the population was divided into two groups that were divergently selected for high and low egg weight. After 8 generations of divergent selection, the lines were maintained by brother-sister mating without selection (PONSUKSILI 1995). In 1987, eggs from the low-egg-weight-selected line were transferred to the Experimental Animal Station of the Technische Universität, Berlin, Germany. In 1988, the inbreeding level in this population was reported to be $94 \%$ by SOMES (1988). As full-sib mating has continued, the inbreeding level in WL77 has 
reached close to $100 \%$. Based on the same marker information as for $\mathrm{NHI}$, the inbreeding level in WL77 is close to $100 \%$. In line WL77, the ejaculate of 4 to 5 males was mixed and used as mixed sample for artificial insemination of 10 to 24 hens per generation until 2008. Since then, the population is maintained in a subpopulation structure of 4 full sibs with a 1:4 male to female mating ratio.

\section{Housing and management}

Since 1993, animals of all lines were housed under the same conditions in the Experimental Animal Station of Humboldt-Universität zu Berlin, Germany. Animals had free access to feed and water. After hatch, animals were fed a starter ration (11.4 MJ ME/kg and $18 \% \mathrm{CP}$ ). Between 8 and 18 weeks, they were fed a grower ration (11.4 MJ ME/kg and 15.5\% CP). From 18 weeks on, they were fed with a production ration (11.2 MJ ME/kg and 17\% CP). Animals were raised on a straw-covered floor from hatching to 17 weeks and then kept in individual cages $(50 \mathrm{~cm} \times 45 \mathrm{~cm} \times 45 \mathrm{~cm})$ until the age of 60 weeks. The floor-space was 1 $\mathrm{m}^{2}$ for 14 one-day-old chickens until 5 weeks of age and $1 \mathrm{~m}^{2}$ for 6 animals from 5 to 17 weeks. All lines were reproduced by artificial insemination in 3 to 7 hatches in early spring once a year. Animals were exposed to a lighting regime, which started at the age of 18 weeks with $15 \mathrm{~h}$ of light per day, increasing by 30 min every two weeks until reaching $17 \mathrm{~h}$ per day at 26 weeks, continuing until 60 weeks. From hatching until one week, animals were kept at $32^{\circ} \mathrm{C}$. Afterwards, the temperature was decreased every week by $2^{\circ} \mathrm{C}$ until seven weeks. From this age on, animals were kept at $18-20^{\circ} \mathrm{C}$.

\section{Phenotypic data}

For the characterization of growth we used 132, 40, and 13 males and 72, 26, and 15 females of $\mathrm{NH}, \mathrm{NHI}$, and WL77 lines, respectively. Body weights (BW) of all animals were measured at hatch, 5, 10, 15, and 20 weeks. Afterwards, males were slaughtered. Females were kept until 60 weeks to collect egg performance data; thus, we also collected body weights at 24, 32, and 56 weeks. Body weight gains (BWG) were calculated as differences between subsequent body weight measurements. For the analysis of body composition, 5 to 620 weeks old males of the inbred lines NHI and WL77 were slaughtered and dissected after $10 \mathrm{~h}$ of fasting. Feathers, heads, skin, feet and shanks were removed. The body composition measurements were classified into inner organ, adipose tissues, and carcass. We measured the weights of hearts, livers, spleens, pancreases and gizzards and the lengths of the intestines. Afterwards, adipose tissues were dissected and weighed: subcutaneous around the neck, adipose tissue around the heart, retroperitoneal below the kidneys, peritoneal sticking to the kidneys, mesenteric sticking to the gizzard, and abdominal around the gonads. Carcass was defined as the remaining empty body. Heads, necks, and left and right breast muscles were weighed, as well as the combined masses of the bones and muscles of left and right wings and thighs and drumsticks. Relative weights were calculated as a percentage of carcass weight.

For the analysis of reproductive traits we recorded the number of eggs (EN), egg weight (EW), age at first egg (AFE), and the egg production ratio (EPR). Eggs were collected every day from the beginning of egg-laying to 60 weeks. Data on the number and weight of eggs were assigned into early and late production phase between 18 to 40 
and 41 to 60 weeks, respectively. Egg weight was measured as the mean weight of two eggs every 4 weeks from the beginning of egg-laying. Egg production ratio (EPR), representing the egg-laying interval between 169 to 280 days, as suggested by Sasaki et al. (2004), was calculated as the number of eggs divided by 111 days.

\section{Statistical analyses}

Analysis of variance (ANOVA) using GLM procedure was performed to test the effects of line, sex, hatch, and interaction between line and sex on growth traits. For the analysis of body composition in males we omitted sex and hatch; for reproduction traits in females we omitted sex. Least-square means (LSM) were calculated for every trait. To test significant differences between animal groups, pair-wise comparisons were performed with the Tukey-Kramer test. Pearson's correlation coefficients between traits were estimated in each line using PROC CORR. All analyses were performed with the SAS package version 9.2 (SAS INSTITUTE 2008).

\section{Results}

\section{Growth}

Due to the selection for high meat yield in $\mathrm{NH}$ and for low egg weight in WL77, the body weight of $\mathrm{NH}$ and $\mathrm{NHI}$ chickens were about twice as high as in WL77 at the age of 20 weeks (Table 1). Interestingly, at hatch, chicks of the outbred NH population were significantly heavier than those of the other lines. They were $8 \mathrm{~g}$ heavier than chicks of $\mathrm{NHI}$ and 10 to $11 \mathrm{~g}$ heavier than chicks of WL77. Despite the chicks low weight at hatch in $\mathrm{NHI}$, the growth rate until 10 weeks was similar to that of $\mathrm{NH}$, and much higher than in WL77 (Figure 1). Afterwards, the weight gain in males of all lines was still positive until 15 weeks, while females' gain slowed down.

\section{Table 1}

Body weights in outbred New Hampshire (NH), partially inbred New Hampshire (NHI), and inbred White Leghorn (WL77) lines at different ages

Körpergewichte in Abhängigkeit vom Alter in der New Hampshire Anzuchtline NH, der partiellen Inzuchtlinie (NHI) und der Inzuchtlinie WL77

\begin{tabular}{lcccccc}
\hline $\begin{array}{l}\text { Age, } \\
\text { weeks }\end{array}$ & $\mathrm{NH}, \mathrm{n}=132$ & $\begin{array}{c}\text { Males } \\
\mathrm{NHI}, \mathrm{n}=40\end{array}$ & WL77, $\mathrm{n}=13$ & $\mathrm{NH}, \mathrm{n}=72$ & $\begin{array}{c}\text { Females } \\
\mathrm{NHI}, \mathrm{n}=26\end{array}$ & WL77, $\mathrm{n}=15$ \\
\hline 0 & $46 \pm 1^{\mathrm{a}}$ & $38 \pm 1^{\mathrm{b}}$ & $36 \pm 1^{\mathrm{b}}$ & $45 \pm 1^{\mathrm{a}}$ & $37 \pm 1^{\mathrm{b}}$ & $34 \pm 1^{\mathrm{b}}$ \\
5 & $576 \pm 5^{\mathrm{a}}$ & $414 \pm 10^{\mathrm{b}}$ & $141 \pm 19^{\mathrm{c}}$ & $518 \pm 7^{\mathrm{a}}{ }^{*}$ & $411 \pm 11^{\mathrm{b}}$ & $141 \pm 17^{\mathrm{c}}$ \\
10 & $1580 \pm 13^{\mathrm{a}}$ & $1245 \pm 22^{\mathrm{b}}$ & $546 \pm 38^{\mathrm{c}}$ & $1268 \pm 14^{\mathrm{a}}{ }^{*}$ & $1157 \pm 22^{\mathrm{b}}$ & $508 \pm 35^{\mathrm{c}}$ \\
15 & $2639 \pm 23^{\mathrm{a}}$ & $2239 \pm 35^{\mathrm{b}}$ & $1046 \pm 48^{\mathrm{c}}$ & $1827 \pm 17^{\mathrm{a}},{ }^{*}$ & $1750 \pm 28^{\mathrm{a}},{ }^{*}$ & $857 \pm 44^{\mathrm{b}},{ }^{*}$ \\
20 & $3009 \pm 28^{\mathrm{a}}$ & $2735 \pm 46^{\mathrm{b}}$ & $1460 \pm 48^{\mathrm{c}}$ & $2185 \pm 18^{\mathrm{a}}{ }^{*}$ & $2123 \pm 28^{\mathrm{a}}{ }^{*}$ & $1098 \pm 44^{\mathrm{b}}{ }^{*}$ \\
24 & & & & $2316 \pm 19^{\mathrm{a}}$ & $2342 \pm 30^{\mathrm{a}}$ & $1181 \pm 49^{\mathrm{b}}$ \\
32 & & & & $2521 \pm 28^{\mathrm{a}}$ & $2567 \pm 45^{\mathrm{a}}$ & $1292 \pm 73^{\mathrm{b}}$ \\
56 & & & $2787 \pm 38^{\mathrm{a}}$ & $2827 \pm 57^{\mathrm{a}}$ & $1478 \pm 92^{\mathrm{b}}$ \\
\hline
\end{tabular}

Superscripts indicate differences in body weight at a specific age: ${ }^{a, b, c}$ differences between lines within sex $(P<0.05)$, * differences between sexes within line $(P<0.05)$. 

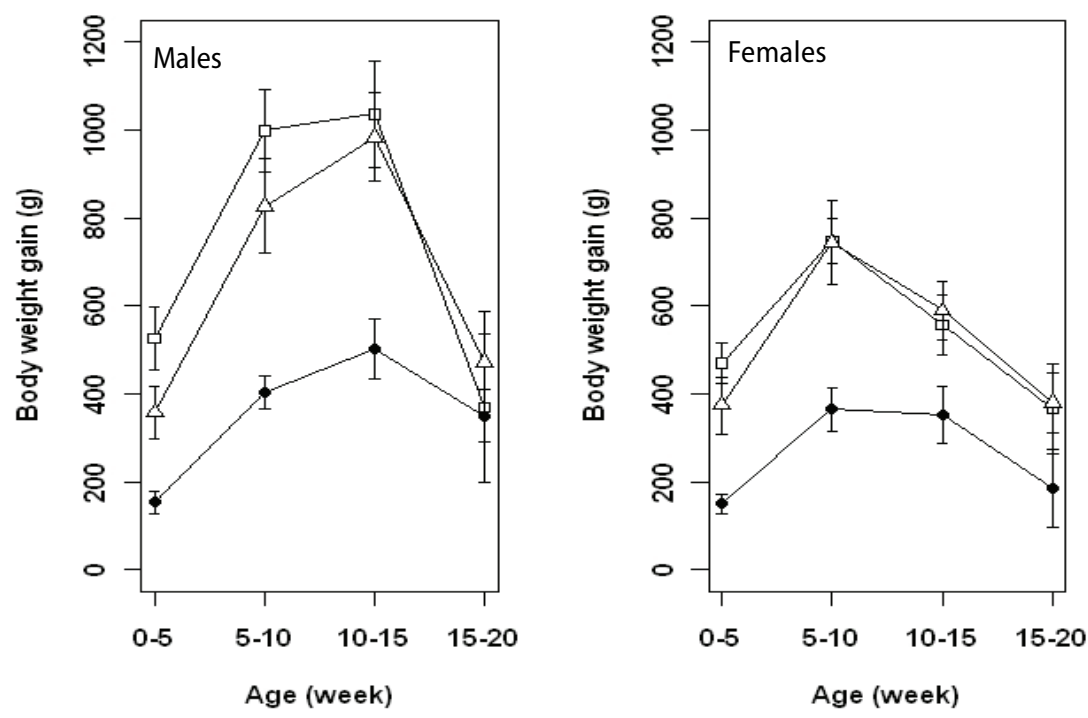

Figure 1

Body weight gains in males (left) and females (right) of outbred New Hampshire, partially inbred New Hampshire, and inbred White Leghorn lines at different ages. $\square=\mathrm{NH}, \Delta=\mathrm{NHI}, \bullet=$ WL77. Animal numbers are given in Table 1.

Altersabhängige Körpergewichtszunahme bei Männchen (links) und Weibchen (rechts)

Sex had an influence on body weight and growth. As expected, females of all lines were lighter than males. The differences became significant in the NH outbred line at 5 weeks and in NHI and WL77 lines at 15 weeks. At 20 weeks, males of all lines were between 1.28 and 1.38 times heavier than females of the same line.

Although the body weights of $\mathrm{NHI}$ and $\mathrm{NH}$ were similar, it is interesting to mention that the weights of $\mathrm{NH}$ and $\mathrm{NHI}$ females did not differ from the age of 15 weeks on, while males of the outbred NH line were $18 \%$ and $10 \%$ heavier than NHI males at 15 and 20 weeks, respectively.

\section{Body composition}

Body compositions were compared between males of the partially inbred line, $\mathrm{NHI}$, and the inbred line, WL77. Consistent with the 2.1 times higher carcass weight, NHI males had 1.7 to 2.4 times higher average masses of carcass parts (head, neck, breast muscle, wing, and drumstick and thigh) than WL77 at 20 weeks (Table 2). As expected, the body composition measurements were highly correlated with carcass-part masses. Therefore, all measurements were also analyzed as a percentage of carcass weight. The ratios of the relative weights of carcass parts to the whole carcass mass between NHI and WL77 are closer to 1, indicating linear growth increase in NHI as compared to WL77. The heart and spleen weights were 2.4 and about 2.5 times higher in NHI as compared to WL77, respectively; liver and pancreas weights were only 1.3 times higher. Gizzard weights did not differ significantly, but NHI chickens had $31 \mathrm{~cm}$ longer intestines. While the heart and spleen weights relative to carcass weight were higher in NHI as compared to WL77, most inner organs were greater in WL77 as compared to $\mathrm{NHI}$, relative to their carcass. These 
results indicate that there is no linear relationship between carcass weight and the weights of inner organs.

The average mass of all collected fat deposits of $\mathrm{NHI}$ males was 9.3 times as heavy as in WL77 (Table 2). The biggest differences were found for abdominal, heart, and neck adipose tissue, which was 16, 9, and 8 times heavier in NHI than in WL77, respectively. The biggest fat depot, in absolute as well as relative weights, was the abdominal adipose tissue, followed by the subcutaneous fat tissue around the neck. The NHI males had $16 \pm$ $1.82 \mathrm{~g}$ fat in the abdominal region and $8 \pm 1.72 \mathrm{~g}$ around the neck. Retroperitoneal and peritoneal adipose tissue weights were small in both lines and did not differ significantly.

Table 2

Absolute and relative body composition measurements in partially inbred New Hampshire (NHI) and inbred White Leghorn (WL77) males at 20 weeks (least square means \pm standard error)

Absolute und relative Parameter der Körperzusammensetzung in der partiellen Inzuchtlinie NHI und der Inzuchtlinie WL77 von männlichen Tieren im Alter von 20 Wochen

\begin{tabular}{|c|c|c|c|c|c|c|}
\hline \multirow{2}{*}{ Measurement } & \multicolumn{3}{|c|}{ Absolute values } & \multicolumn{3}{|c|}{ Values relative to carcass weight } \\
\hline & $\mathrm{NHI}, \mathrm{n}=6$ & WL77, $n=5$ & NHI:WL77 & $\mathrm{NHI}, \mathrm{n}=6$ & WL77, n=5 & NHI:WL77 \\
\hline \multicolumn{7}{|l|}{ Carcass } \\
\hline Carcass weight, g & $1915 \pm 38^{\mathrm{a}}$ & $909 \pm 41^{b}$ & 2.1 & & & \\
\hline Head weight, g & $227 \pm 6^{a}$ & $119 \pm 6^{b}$ & 1.9 & $11.9 \pm 0.30^{\mathrm{b}}$ & $13.1 \pm 0.33^{\mathrm{a}}$ & 0.9 \\
\hline Neck weight, g & $87 \pm 3^{a}$ & $50 \pm 4^{b}$ & 1.7 & $4.5 \pm 0.16^{b}$ & $5.5 \pm 0.18^{\mathrm{a}}$ & 0.8 \\
\hline Breast muscle weight, g & $342 \pm 11^{a}$ & $178 \pm 13^{b}$ & 1.9 & $17.8 \pm 0.45^{b}$ & $19.6 \pm 0.49^{a}$ & 0.9 \\
\hline Wing weight, $g$ & $251 \pm 6^{a}$ & $110 \pm 6^{b}$ & 2.3 & $13.1 \pm 0.29^{a}$ & $12.1 \pm 0.32^{b}$ & 1.1 \\
\hline Drumstick \& thigh weight, $g$ & $690 \pm 17^{\mathrm{a}}$ & $292 \pm 18^{b}$ & 2.4 & $36.0 \pm 0.43^{a}$ & $32.0 \pm 0.48^{b}$ & 1.1 \\
\hline \multicolumn{7}{|l|}{ Inner organs } \\
\hline Heart, $g$ & $12 \pm 0.32^{\mathrm{a}}$ & $5 \pm 0.35^{b}$ & 2.4 & $0.6 \pm 0.02^{\mathrm{a}}$ & $0.5 \pm 0.02^{b}$ & 1.2 \\
\hline Liver, $\mathrm{g}$ & $35 \pm 1.08^{\mathrm{a}}$ & $27 \pm 1.19^{b}$ & 1.3 & $1.8 \pm 0.08^{b}$ & $3.0 \pm 0.08^{\mathrm{a}}$ & 0.6 \\
\hline Spleen, $g$ & $5 \pm 0.19^{a}$ & $2 \pm 0.21^{b}$ & 2.5 & $0.3 \pm 0.01^{\mathrm{a}}$ & $0.2 \pm 0.01^{b}$ & 1.5 \\
\hline Pancreas, $\mathrm{g}$ & $4 \pm 0.21^{\mathrm{a}}$ & $3 \pm 0.23^{b}$ & 1.3 & $0.2 \pm 0.01^{b}$ & $0.4 \pm 0.01^{\mathrm{a}}$ & 0.5 \\
\hline Gizzard, g & $37 \pm 1.02^{\mathrm{a}}$ & $33 \pm 1.12^{\mathrm{a}}$ & 1.1 & $1.9 \pm 0.08^{b}$ & $3.7 \pm 0.09^{\mathrm{a}}$ & 0.5 \\
\hline Intestine length, $\mathrm{cm}$ & $168 \pm 2.81^{\mathrm{a}}$ & $137 \pm 3.08^{b}$ & 1.2 & $8.8 \pm 0.34^{b}$ & $15.1 \pm 0.38^{\mathrm{a}}$ & 0.6 \\
\hline \multicolumn{7}{|l|}{ Adipose tissues } \\
\hline Neck, g & $8.00 \pm 1.72^{\mathrm{a}}$ & $1.00 \pm 1.88^{b}$ & 8.0 & $0.423 \pm 0.09^{\mathrm{a}}$ & $0.147 \pm 0.10^{\mathrm{a}}$ & 2.9 \\
\hline Heart, $g$ & $0.90 \pm 0.05^{\mathrm{a}}$ & $0.10 \pm 0.05^{b}$ & 9.0 & $0.050 \pm 0.00^{\mathrm{a}}$ & $0.015 \pm 0.00^{b}$ & 3.3 \\
\hline Retroperitoneal, g & $0.23 \pm 0.11^{\mathrm{a}}$ & $0.02 \pm 0.12^{\mathrm{a}}$ & 11.5 & $0.013 \pm 0.01^{\mathrm{a}}$ & $0.002 \pm 0.01^{a}$ & 6.5 \\
\hline Peritoneal, $\mathrm{g}$ & $0.07 \pm 0.06^{\mathrm{a}}$ & $0.04 \pm 0.06^{\mathrm{a}}$ & 1.8 & $0.003 \pm 0.00^{\mathrm{a}}$ & $0.004 \pm 0.00^{\mathrm{a}}$ & 0.7 \\
\hline Mesenteric, g & $2.20 \pm 0.39^{\mathrm{a}}$ & $0.80 \pm 0.42^{b}$ & 2.8 & $0.116 \pm 0.02^{\mathrm{a}}$ & $0.088 \pm 0.03^{a}$ & 1.3 \\
\hline Abdominal, g & $16.00 \pm 1.82^{\mathrm{a}}$ & $1.00 \pm 2.00^{\mathrm{b}}$ & 16.0 & $0.858 \pm 0.09^{\mathrm{a}}$ & $0.088 \pm 0.01^{b}$ & 9.8 \\
\hline Total adipose tiss. weight, $\mathrm{g}$ & $27.40 \pm 3.30^{\mathrm{a}}$ & $2.96 \pm 3.61^{\mathrm{b}}$ & 9.3 & $1.431 \pm 0.18^{\mathrm{a}}$ & $0.327 \pm 0.19^{b}$ & 4.4 \\
\hline
\end{tabular}

a,b differences in absolute or relative trait values between lines $(P<0.05)$

\section{Reproductive traits}

The three lines can be ordered according to their performance for most of the egg production traits from high to low as NH, NHI, and WL77 (Table 3). As a correlated result of selection for low egg weight, WL77 chickens had the lowest performance for average weekly number of eggs during the entire experimental period (Figure 2). NHI had higher reproductive traits than WL77 females, except for EW18-40 and age at first egg, in which they did not differ significantly from each other. The NH females reached sexual maturity 
earlier than WL77 females. On average, NH females laid their first egg 19 days earlier than WL77 females did. This is consistent with the earlier end to the phase of fastest growth and roughly double body weight at 20 weeks in NH as compared to WL77 females. Consequently, the average number of eggs in the first phase between 18 and 40 weeks is higher in $\mathrm{NH}$ as compared to WL77; in the second phase between 41 and 60 weeks, the egg number did not differ significantly. The total egg number in $\mathrm{NH}$ was 1.27 times higher than in WL77. The egg weight of NH females was consistently higher than in WL77, on average 1.28 times as much as in WL77 between 18 and 60 weeks.

Table 3

Reproductive traits in females of outbred New Hampshire (NH), partially inbred New Hampshire (NHI), and inbred White Leghorn (WL77) (least square means \pm standard error)

Reproduktionsmerkmale von Weibchen

\begin{tabular}{|c|c|c|c|c|}
\hline Trait & Age, weeks & $\mathrm{NH}, \mathrm{n}=72$ & $\mathrm{NHI}, \mathrm{n}=26$ & WL77, $n=15$ \\
\hline Age at first egg, days & & $136 \pm 1^{\mathrm{a}}$ & $146 \pm 2^{b}$ & $155 \pm 4^{b}$ \\
\hline Egg production ratio & & $85 \pm 2^{\mathrm{a}}$ & $88 \pm 2^{a}$ & $65 \pm 4^{b}$ \\
\hline Eggs number & $\begin{array}{l}18-40 \\
41-60 \\
18-60\end{array}$ & $\begin{array}{r}114 \pm 2^{\mathrm{a}} \\
74 \pm 2^{\mathrm{b}} \\
185 \pm 4^{\mathrm{b}}\end{array}$ & $\begin{array}{r}110 \pm 3^{a} \\
94 \pm 3^{a} \\
204 \pm 6^{a}\end{array}$ & $\begin{array}{c}77 \pm 6^{b} \\
64 \pm 6^{b} \\
146 \pm 10^{c}\end{array}$ \\
\hline Eggs weight, $\mathrm{g}^{*}$ & $\begin{array}{l}18-40 \\
41-60 \\
18-60\end{array}$ & $\begin{array}{l}54 \pm 1^{\text {a }} \\
66 \pm 1^{\text {a }} \\
59 \pm 1^{\text {a }}\end{array}$ & $\begin{array}{l}45 \pm 1^{\mathrm{b}} \\
60 \pm 1^{\mathrm{b}} \\
52 \pm 1^{\mathrm{b}}\end{array}$ & $\begin{array}{l}42 \pm 1^{b} \\
50 \pm 2^{c} \\
46 \pm 2^{c}\end{array}$ \\
\hline
\end{tabular}

Superscripts indicate differences in reproductive traits at specific ages: ${ }^{a, b}, \mathrm{c}$ differences between lines $(P<0.05)$, ${ }^{*}$ mean weight of all eggs per line.

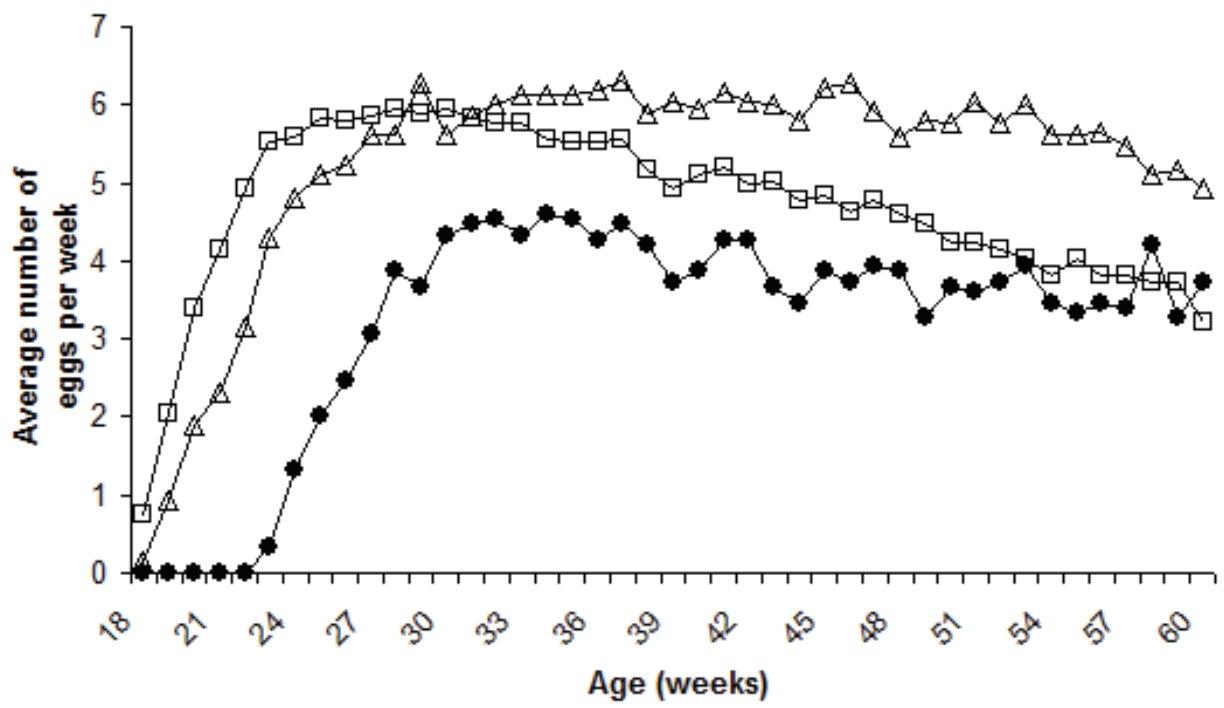

Figure 2

Average number of eggs per week in outbred New Hampshire (NH), partially inbred New Hampshire (NHI), and inbred White Leghorn (WL77) lines. $\square=\mathrm{NH}, \Delta=\mathrm{NHI}, \bullet=$ WL77

Durchschnittliche wöchentliche Legeleistung 
Table 4

Pearson's correlation coefficients between reproductive and body weight traits in outbred New Hampshire (NH), partially inbred New Hampshire (NHI), and inbred White Leghorn (WL77) females until the age of 60 weeks.

Pearson's Korrelationskoeffizienten zwischen Reproduktionsmerkmalen und Körpergewicht von Hennen bis zum Alter von 60 Wochen

\begin{tabular}{|c|c|c|c|c|c|c|c|c|c|}
\hline \multirow{2}{*}{ Parameter } & \multirow{2}{*}{$\begin{array}{l}\text { Age, } \\
\text { weeks }\end{array}$} & \multirow{2}{*}{$\begin{array}{c}\text { Age at } \\
\text { first egg }\end{array}$} & \multirow{2}{*}{ EPR } & \multicolumn{3}{|c|}{ Egg number } & \multicolumn{3}{|c|}{ Egg weight } \\
\hline & & & & $18-40$ & $41-60$ & $18-60$ & $18-40$ & $41-60$ & $18-60$ \\
\hline $\begin{array}{l}N H, n=72 \\
\text { Egg production ratio }\end{array}$ & & $(-0.15)$ & & & & & & & \\
\hline Egg number & $\begin{array}{l}18-40 \\
41-60 \\
18-60\end{array}$ & $\begin{array}{c}-0.45^{* * *} \\
(0.14) \\
(-0.16)\end{array}$ & $\begin{array}{l}0.88^{* * *} \\
0.31^{*} \\
0.81^{* * *}\end{array}$ & $\begin{array}{l}(0.16) \\
0.76^{* * *}\end{array}$ & $0.81^{* * *}$ & & & & \\
\hline Egg weight & $\begin{array}{l}18-40 \\
41-60 \\
18-60\end{array}$ & $\begin{array}{l}(0.03) \\
(0.06) \\
(0.10)\end{array}$ & $\begin{array}{r}(0.13) \\
(-0.05) \\
(0.20)\end{array}$ & $\begin{array}{c}(0.001) \\
(-0.16) \\
(0.03)\end{array}$ & $\begin{array}{r}(-0.07) \\
(0.16) \\
(0.18)\end{array}$ & $\begin{array}{c}(0.07) \\
(0.01) \\
0.27^{*}\end{array}$ & $\begin{array}{l}0.77^{* * * *} \\
0.90^{* * *}\end{array}$ & $0.95^{* * *}$ & \\
\hline Body weight & $\begin{array}{c}0 \\
5 \\
15 \\
24\end{array}$ & $\begin{array}{r}(0.11) \\
(-0.15) \\
(0.09) \\
0.25^{*}\end{array}$ & $\begin{array}{l}(-0.02) \\
-0.34^{* *} \\
(-0.15) \\
(-0.04)\end{array}$ & $\begin{array}{l}(-0.002) \\
(-0.22) \\
-0.26^{*} \\
(-0.21)\end{array}$ & $\begin{array}{r}(-0.02) \\
(-0.08) \\
(0.18) \\
(0.19)\end{array}$ & $\begin{array}{l}(-0.02) \\
-0.26^{*} \\
(-0.06) \\
(-0.04)\end{array}$ & $\begin{array}{r}(0.21) \\
(-0.06) \\
(0.19) \\
(0.13)\end{array}$ & $\begin{array}{l}(0.23) \\
(0.02) \\
(0.23) \\
(0.17)\end{array}$ & $\begin{array}{r}(0.19) \\
(-0.11) \\
(0.21) \\
(0.14)\end{array}$ \\
\hline
\end{tabular}

NHI, $n=26$

Egg production ratio

$-0.71^{* * *}$

Egg number

$18-40-0.84^{* * *} \quad 0.96^{* * *}$

$41-60-0.68^{* * *} \quad 0.75^{* * *} 0.78^{* * *}$

$18-60-0.82^{* * *} \quad 0.93^{* * *} \quad 0.97^{* * *} \quad 0.91^{* * *}$

Egg weight

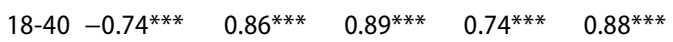

$\begin{array}{llll}41-60-0.53^{* *} \quad 0.63^{* *} & 0.62^{* * *} & 0.59^{* *} & 0.64^{* * *}\end{array}$

$18-60-0.69^{* * *} \quad 0.81^{* * *} \quad 0.84^{* *} \quad 0.73^{* * *} \quad 0.84^{* * *} \quad 0.98^{* * *} \quad 0.90^{* * *}$

Body weight

$\begin{array}{ccccccccc}0 & 0.64^{* * *} & -0.64^{* * *} & -0.73^{* * *} & -0.46^{*} & -0.66^{* * *} & -0.70^{* * *} & -0.49^{*} & -0.67^{* * *} \\ 5 & -0.60^{* *} & 0.56^{* *} & 0.59^{* *} & 0.53^{* *} & 0.60^{* *} & 0.44^{*} & 0.46^{*} & 0.45^{*} \\ 15 & -0.61^{* *} & 0.53^{* *} & 0.56^{* *} & 0.56^{* *} & 0.60^{* *} & 0.53^{* *} & 0.57^{* *} & 0.56^{* *} \\ 24 & (0.20) & (-0.14) & (-0.14) & (0.05) & (-0.07) & (0.06) & 0.39^{*} & (0.20)\end{array}$

WL77, $n=15$

Egg production ratio

(0.10)

Egg number

$18-40(-0.12)$

$41-60(-0.17)$

$0.97^{* * *}$

$18-60(-0.17)$

(0.48) (0.49)

$0.74^{* *} \quad 0.77^{* * *} \quad 0.93^{* * *}$

Egg weight

$\begin{array}{llllll}18-40 & (0.41) \quad(0.05) & (-0.10) & (-0.27) & (-0.25)\end{array}$

$41-60(-0.24) \quad(0.22) \quad(0.30) \quad(0.13) \quad(0.22) \quad(-0.13)$

$18-60(-0.05) \quad(0.05) \quad(0.04) \quad(-0.05) \quad(-0.02) \quad(0.46) \quad 0.76^{* *}$

Body weight

\begin{tabular}{crrrrrrrr}
0 & $(-0.17)$ & $(-0.42)$ & $(-0.46)$ & $(-0.13)$ & $(-0.29)$ & $(0.03)$ & $(0.02)$ & $(0.13)$ \\
5 & $(-0.16)$ & $(0.05)$ & $(0.08)$ & $(-0.36)$ & $(-0.23)$ & $(-0.01)$ & $(-0.33)$ & $(-0.33)$ \\
15 & $(-0.26)$ & $(0.46)$ & $0.54^{*}$ & $(-0.11)$ & $(0.15)$ & $(-0.12)$ & $(0.21)$ & $(0.09)$ \\
24 & $(-0.21)$ & $(-0.23)$ & $(-0.17)$ & $(-0.02)$ & $(-0.08)$ & $(-0.04)$ & $0.57^{*}$ & $0.56^{*}$ \\
\hline
\end{tabular}

EPR egg production ratio, significant correlations between traits at ${ }^{*} P<0.05,{ }^{* *} P<0.01,{ }^{* * *} P<0.001$, respectively; non-significant correlation coefficients are given in brackets

Considering only $\mathrm{NH}$ and $\mathrm{NHI}$ females, both lines had better performance than WL77 females. The egg production ratios were 85 and 88 in $\mathrm{NH}$ and $\mathrm{NHI}$, respectively, compared to WL77 with 65. If we compare the average number of eggs per week in $\mathrm{NH}$ and $\mathrm{NHI}$ females, we find that $\mathrm{NH}$ performed better than NHI until 30 weeks (Figure 2). Afterwards, 
the partial inbred $\mathrm{NHI}$ line is even more productive than the $\mathrm{NH}$. Due to the later onset of laying eggs in $\mathrm{NHI}$, compared to $\mathrm{NH}$, the highest average number of eggs per week is reached later in $\mathrm{NHI}$ but kept nearly constant over about 20 weeks. On the other hand, the average number of eggs per week decreased slowly in $\mathrm{NH}$ after having reached a maximum of 6 eggs per week around 30 weeks. The egg weight was always lower in $\mathrm{NHI}$ than in $\mathrm{NH}$, but still higher than in WL77. The average egg weight of NHI between 18 to 60 weeks was in between those of $\mathrm{NH}$ and WL77. The total egg masses produced by $\mathrm{NH}$, $\mathrm{NHI}$, and WL77 were 10.9, 10.6, and $6.7 \mathrm{~kg}$, respectively.

\section{Correlation between traits}

The most significant correlations between traits were consistently found within the $\mathrm{NHI}$ line (Table 4). Specifically, high negative correlations were found between age at first egg and egg number, egg weight, and body weight $(-0.53>r>-0.84)$. As compared to the $\mathrm{NHI}$ line, the $\mathrm{NH}$ line showed negative correlation of age at first egg to egg number $(r=-0.45)$ while the WL77 showed no significant correlations involving age at first egg. However, missing significance in the WL77 line could result from the low animal number (15). In tendency, there is also a negative correlation between body weight at hatch and egg number as in the other lines. Additionally, the body weight of newly-hatched $\mathrm{NHI}$ chicks was negatively correlated to the number and weight of their eggs during the entire period of egg-laying $(-0.46>r>-0.73)$. Thus, the lower hatch weight of chicks in $\mathrm{NHI}$ than in $\mathrm{NH}$ could be the reason for the lower total egg mass in NHI. At week 15, body weight of $\mathrm{NHI}$ hens showed positive correlation to egg number $(0.56<\mathrm{r}<0.60)$ and egg weight $(0.53<r<0.57)$, which was not found in the two other lines.

\section{Discussion}

The analyzed New Hampshire and White Leghorn lines originate from distinct genetic base populations. Therefore, we expect different alleles at many loci, including some that contributed to the selection for high meat yield and low egg weight in the history of the lines.

The present results clearly demonstrate that the chicken of the outbred $\mathrm{NH}$ and partially inbred $\mathrm{NHI}$ lines have higher mean growth performance than those in the inbred WL77 line. This is due to the positive selection for high meat yield in NH and low egg weight in WL77. As the weight of chicks at hatch are largely determined by the maternal effect of egg size (MURAMATSU et al. 1990, GRIFFIN and GODDARD 1994), the smaller egg size of the WL77 dams is largely responsible for the significantly lower body weights at hatch in this line compared to $\mathrm{NH}$. The higher hatch weight of $\mathrm{NH}$ chicks as compared to NHI chicks is in line with DEEB and LAMONT (2002), who compared outbred and inbred Leghorn and Fayoumi lines. They also found that the outbred population had higher hatch weights than the inbred lines. Like in many other chicken populations (DEEB and LAMONT 2002, EL-GENDY et al. 2007), in all investigated lines, the growth rates of males were higher than in females. The magnitude of sex-difference varied between the lines.

For body composition we only had data for the lines NHI and WL77. Corresponding with the faster growth and twice as high body weight, NHI chickens also had heavier 
carcass parts. Despite higher absolute mass of inner organs in $\mathrm{NHI}$, most inner organs were proportionally larger in WL77 than in NHI. These finding indicate that the masses of inner organs is dependent on their physiological functions rather than on selection pressure.

Fat deposition is an important trait in the poultry industry. High fat levels are considered an indicator of low commercial value. Its deposition in large amounts can depress feed efficiency (JENNEN et al. 2004). In agreement with findings on other populations of rapidly growing chickens (HOOD 1984), the NHI line deposited more fat than the WL77. CHAMBERS (1990) even reported that the differences in body weight of various breeds depend upon differences in abdominal fat weight.

As a result of long term selection, WL77 had the highest age at first egg, a low number of eggs and the lightest eggs. The higher age at first egg in WL77 hens indicates that this line reaches sexual maturity later in life than the other lines. This is in line with the lower body weight in this line. The mean value we obtained for age at first egg in the inbred WL77 line (155) is similar to the value reported by SZWACZKOWSKI et al. (2003) in another inbred White Leghorn population (156.2). The same authors reported a mean of $59.2 \mathrm{~g}$ for egg weight, which was higher than in our inbred WL77 line. The higher age at first egg in our WL77 inbred line compared to other White Leghorn populations (SASAKI et al. 2004, TUISKULA-HAAVISTO et al. 2004) is due to the correlated response of selection for low egg weight before inbreeding.

Inbreeding of WL77 did not likely contribute to the low egg weights and numbers, as only the fittest animals were reproduced and high vigor was maintained during inbreeding over many generations. However, inbreeding could play a role in $\mathrm{NHI}$, as compared to $\mathrm{NH}$, in addition to random fixation of alleles contributing to performance. The egg laying performance of the NHI line was between the values of NH and WL77 until 30 weeks of age. Afterwards, the NHI line had the best performance for average weekly number of eggs. This increase in performance of NHI females in the late production period can be due to the positive combined effects of inbreeding and selection of animals with the highest egg number at the age when animals were reproduced.

Unlike in other studies (LUBRITZ and SMITH 1996, LWELAMIRA et al. 2009), we found negative correlations between age at first egg and most other egg production traits in all three lines. Similarly, LWELAMIRA et al. (2009) reported phenotypic correlation of -0.16 between age at first egg and egg number. The negative correlation implies that chickens with high ages at first egg not only reach their sexual maturity later in life, but they also produce a lower number of eggs than those having the first egg earlier.

In conclusion, the presented inbred White Leghorn WL77 line and the partial inbred line New Hampshire are two new inbred or nearly inbred lines that can facilitate genetic research in the future to uncover genetic causes of various phenotypic traits. Such experiments are underway. As a result of selection for different traits in the base populations of the inbred lines, the two presented inbred lines differ extremely in all analyzed body weight, growth, and body composition traits, as well as in age of sexual maturity and egg-laying performance. Despite inbreeding, the presented lines have high vigor. Their unique fixation of alleles make them ideal resources in the search for genes contributing to variation in different traits. 


\section{Acknowledgements}

Zemelak Sahle was supported by the DAAD and Mostafa K. Nassar by Yousef Jameel Foundation. We acknowledge Jacob Litke of Wesleyan University in Middletown, Connecticut, for his comments and Annett Kannegießer of the Experimental Animal Station at Humboldt-Universität zu Berlin, Germany, for assistance in data collection.

\section{References}

Buitenhuis AJ, Rodenburg TB, Wissink PH, Visscher J, Koene P, Bovenhuis H, Ducro BJ, van der Poel JJ (2004) Genetic and phenotypic correlations between feather pecking behavior, stress response, immune response, and egg quality traits in laying hens. Poult Sci 83, 1077-82

Burt DW, White SJ (2007) Avian genomics in the 21st century. Cytogenet Genome Res 117, 6-13

Campos RL, Nones K, Ledur MC, Moura AS, Pinto LF, Ambo M, Boschiero C, Ruy DC, Baron EE, Ninov K, et al. (2009) Quantitative trait loci associated with fatness in a broiler-layer cross. Anim Genet 40, 729-36

Carlborg O, Brockmann GA, Haley CS (2005) Simultaneous mapping of epistatic QTL in DU6i $\times$ DBA/2 mice. Mamm Genome 16, 481-94

Chambers JR (1990) Genetics of growth and meat production in chickens. In: Crawford RD (ed) Poultry breeding and genetics, Elsevier, Amsterdam, Netherlands, 599-643

Deeb N, Lamont SJ (2002) Genetic architecture of growth and body composition in unique chicken populations. J Hered 93, 107-18

Dennis R, Zhang HM, Bacon LD, Estevez I, Cheng HW (2004) Behavioral and physiological features of chickens diversely selected for resistance to Avian Disease. 1. Selected inbred lines differ in behavioral and physical responses to social stress. Poult Sci 83, 1489-96

El-Gendy EA, Nassar MK, Mostageer A (2007) Genotype-Environment interaction in relation to heat tolerance in chickens. 2. Variation in juvenile growth of warm regions' oriented breeds. Int J Poult Sci 6, 322-8

Gaya L, Ferraz J, Rezende F, Mourao G, Mattos E, Eler J, Michelan Filho T (2006) Heritability and genetic correlation estimates for performance and carcass and body composition traits in a male broiler line. Poult Sci 85, 837-43

Griffin HD, Goddard C (1994) Rapidly growing broiler (meat-type) chickens: their origin and use for comparative studies of the regulation of growth. Int J Biochem 26, 19-28

Hansen C, Yi N, Zhang YM, Xu S, Gavora J, Cheng HH (2005) Identification of QTL for production traits in chickens. Anim Biotechnol 16, 67-79

Hartmann C, Johansson K, Strandberg E, Rydhmer L (2003) Genetic correlations between the maternal genetic effect on chick weight and the direct genetic effects on egg composition traits in a White Leghorn line. Poult Sci 82, 1-8

Hood RL (1984) Cellular and Biochemical Aspects of Fat Deposition in the Broiler Chicken. Worlds Poultry Science Journal 40, 160-69

Irgang K (2001) Comparison of the development of inbreeding and homozygosity based on genetic markers in a closed New Hampshire population. Thesis, FB Veterinärmedizin, FU Berlin, Germany, 130-3 [in German]

Jennen DG, Vereijken AL, Bovenhuis H, Crooijmans RP, Veenendaal A, van der Poel JJ, Groenen MA (2004) Detection and localization of quantitative trait loci affecting fatness in broilers. Poult Sci 83, 295-301

Juul-Madsen HR, Dalgaard TS, Rontved CM, Jensen KH, Bumstead N (2006) Immune response to a killed infectious bursal disease virus vaccine in inbred chicken lines with different major histocompatibility complex haplotypes. Poult Sci 85, 986-98

Kamali MA, Ghorbani SH, Sharbabak MM, Zamiri MJ (2007) Heritabilities and genetic correlations of economic traits in Iranian native fowl and estimated genetic trend and inbreeding coefficients. Br Poult Sci 48, 443-8

Kim DK, Lillehoj HS, Hong YH, Park DW, Lamont SJ, Han JY, Lillehoj EP (2008) Immune-related gene expression in two B-complex disparate genetically inbred Fayoumi chicken lines following Eimeria maxima infection. Poult Sci 87, 433-43

Le Bihan-Duval E, Berri C, Baeza E, Millet N, Beaumont C (2001) Estimation of the genetic parameters of meat characteristics and of their genetic correlations with growth and body composition in an experimental broiler line. Poult Sci 80, 839-43 
Lonergan SM, Deeb N, Fedler CA, Lamont SJ (2003) Breast meat quality and composition in unique chicken populations. Poult Sci 82, 1990-4

Lubritz DL, Smith JL (1996) Genetic parameter estimates for egg production in dwarf broiler breeders. J Appl Poult Res 5, 305-10

Lwelamira J, Kifaro G, Gwakisa P (2009) Genetic parameters for body weights, egg traits and antibody response against Newcastle Disease Virus (NDV) vaccine among two Tanzania chicken ecotypes. Trop Anim Health Prod 41, 51-9

McElroy JP, Kim JJ, Harry DE, Brown SR, Dekkers JC, Lamont SJ (2006) Identification of trait loci affecting white meat percentage and other growth and carcass traits in commercial broiler chickens. Poult Sci $85,593-605$

Muramatsu T, Hiramoto K, Okumura J (1990) Strain differences in whole-body protein turnover in the chicken embryo. Br Poult Sci 31, 91-9

Ponsuksili S (1995) Estimation of genetic variation within and between different chicken lines by DNA fingerprinting. Thesis, Faculty of Agriculture and Horticulture, Humboldt Universitat zu Berlin, Germany.

Sasaki O, Odawara S, Takahashi H, Nirasawa K, Oyamada Y, Yamamoto R, Ishii K, Nagamine Y, Takeda H, Kobayashi E, Furukawa T (2004) Genetic mapping of quantitative trait loci affecting body weight, egg character and egg production in $\mathrm{F}_{2}$ intercross chickens. Anim Genet 35, 188-94

SAS Institute (2008) SAS user's guide: statistics, version 9.2. Cary Inc., NC, USA

Schreiweis MA, Hester PY, Settar P, Moody DE (2006) Identification of quantitative trait loci associated with egg quality, egg production, and body weight in an F2 resource population of chickens. Anim Genet 37, 106-12

Somes RG (1988) International registry of poultry genetic stocks. Storrs agricultural experiment station, the university of Connecticut storrs, Connecticut 06268. Document number bulletin 476, 3

Szwaczkowski T, Cywa-Benko K, Wężyk S (2003) A note on inbreeding effect on productive and reproductive traits in laying hens. Animal Science Papers and Reports 21,121-9

Tuiskula-Haavisto M, de Koning DJ, Honkatukia M, Schulman NF, Maki-Tanila A, Vilkki J (2004) Quantitative trait loci with parent-of-origin effects in chicken. Genet Res 84, 57-66

Tuiskula-Haavisto M, Honkatukia M, Vilkki J, de Koning DJ, Schulman NF, Maki-Tanila A (2002) Mapping of quantitative trait loci affecting quality and production traits in egg layers. Poult Sci 81, 919-27

Wei M, van der Werf JH (1995) Genetic correlation and heritabilities for purebred and crossbred performance in poultry egg production traits. J Anim Sci 73, 2220-6

Wolc A, Lisowski M, Szwaczkowski T (2007) Genetic evaluation of laying hens under fixed regression animal models. Arch Tierz 50, 279-87

Zhang W, Aggrey S, Pesti G, Edwards H, Jr, Bakalli R (2003) Genetics of phytate phosphorus bioavailability: heritability and genetic correlations with growth and feed utilization traits in a randombred chicken population. Poult Sci 82, 1075-9

Zhou H, Deeb N, Evock-Clover CM, Ashwell CM, Lamont SJ (2006) Genome-wide linkage analysis to identify chromosomal regions affecting phenotypic traits in the chicken. I. Growth and average daily gain. Poult Sci 85, 1700-11

Zhou H, Deeb N, Evock-Clover CM, Ashwell CM, Lamont SJ (2006) Genome-wide linkage analysis to identify chromosomal regions affecting phenotypic traits in the chicken. II. Body composition. Poult Sci 85, 1712-21

Zhou H, Deeb N, Evock-Clover CM, Mitchell AD, Ashwell CM, Lamont SJ (2007) Genome-wide linkage analysis to identify chromosomal regions affecting phenotypic traits in the chicken. III. Skeletal integrity. Poult Sci 86, 255-66

Zhou H, Lamont SJ (1999) Genetic characterization of biodiversity in highly inbred chickenlines by microsatellite markers. Anim Genet 30, 256-64

Received 12 January 2010, accepted 13 April 2010.

Corresponding author:

GUDRUN A. BROCKMANN

email: gudrun.brockmann@agrar.hu-berlin.de

Breeding Biology and Molecular Genetics, Department for Crop and Animal Sciences, Faculty of Agriculture and Horticulture, Humboldt-Universität zu Berlin, Invalidenstraße 42, 10115 Berlin, Germany 